\title{
Legal bases of sports activity as an object of the theory of system organization
}

\author{
Maryna Korolova
}

Kharkiv State Academy of Physical Culture, Kharkiv, Ukraine

Today, the state of development of the sphere of physical culture and sports is characterized by the presence of organizational and legal problems at the level of functioning of all its components (physical education, professional or mass sport, etc.) on the way to solving socially significant social problems. The lack of an objective assessment of the current state of the public relations industry, which is covered by physical education and sports, taking into account the state policy of Ukraine's integration with the international community, leads to the process of assimilation of this industry in favor of a stronger partnership, which is being formed.

Purpose: to analyze the activities of physical education and sports organizations from the position of conceptual provisions of the theory of system organization.

Material \& Methods: analysis of literary sources; analysis of documents; system analysis; historicism method; a method of analogy of observed patterns; mathematical modeling method.

Results: the problem of managing complex social systems in the context of the functioning of the sports law industry is considered. The theoretical foundations of self-organization of collective interdependent relations in the field of physical culture are substantiated from the position of conceptual provisions of the theory of system organization.

Conclusions: it has been established that at the present stage of development of public sports associations, the international sports movement and international sports federations, successful managerial activity can only be based on the condition that it is built on the basis of systems theory. It is established that the process of formation of interdependent relationships is based on the general principles of interaction of the object in question and its environment. It is the interaction of the object and the environment as a whole that acts as one of the determining principles of effective management and the key to maintaining the equilibrium state of the system.

Keywords: system, sports law, physical education and sports, theory, environment, interaction.

\section{Introduction}

The source of law is the dynamics of the organization of behavior in the corresponding social structure generated by the statistical principle of the formation of general, mutually dependent relations in it. Depending on the social groups that have developed on the basis of existing relations with their own rules and obligations, enshrined in customs or laws for each zone of the statistical distribution of groups, united by any signs of a ranked category of persons, determining norms of their legal behavior are formed. The stability of social conditions leads to the same stability of the reproduction of the corresponding forms of behavior [10].

The state, as the organization of the political power of society, exercises its control, protects its economic and social structure, is an open system and, to ensure its viability, requires systematic replenishment of the necessary potential for energy-mass exchange of services. The decisive role in the distribution of the available potential between the various structural elements and their sectors is played by competitive relations, and in them the economical use of the necessary part of the energy-mass-exchange potential distributed by them [6].

The functioning of the sphere of physical culture, as a specific state structure or its industry, is strictly determined by the level of organization of a holistic social system and cannot be copied or created by analogs of more developed social entities, to a certain extent affects the efficiency of the creation and functioning of various types of associations, unions, federations. The state of physical education is currently at the level of survival with clearly violated relationships between the functioning of their private components in meeting the needs of society. The lack of an objective assessment of the current state of the whole field of public relations, which is covered by physical culture in the inevitable integration of Ukraine into the international community, leads to the process of assimilation of this industry in favor of a stronger part in the partnership that is being formed. The successful functioning of the branch of law in the field of physical culture in the legal regulation of legislation in the government of Ukraine can and should be organized on the modern achievements of the science of managing complex social systems, self-organizing in the conditions of their development in tolerant spaces, using the capabilities of modern computer technology that provides the necessary processing information and decision making. Analysis of recent research and publications. The relevance of the problem of managing complex social systems is confirmed by the attention of scientists.

Thus, theories of systemic organization are found in the works of L. Bartalanfi [16], K. P. Anokhin [1], L. A. Zadeh [17], G. Hagan [14] and other scientists. In our opinion, it is worth noting the special contribution to the study of systems, selforganizing by such authors as W. R. Ashby [15] V. M. Samsonkin, V. A. Druz, E. S. Fedorovich [13], A. A. Voronov [4], A. A. Denisov, D. N. Kolesnikov [7], I. Prigogine [12] and others. At the same time, the dynamic development of social relations, as well as complications of the mechanisms of their legal regulation, in particular in the field of physical education, determine the necessity and relevance of our study.

Purpose of the study is to clarify and justify the theoretical foundations of self-organization of collective interdependent relations in the field of physical culture from the position of conceptual provisions of the theory of system organization. 


\section{SLOBOZANS'KIJ NAUKOVO-SPORTIVNIJ VISNIK}

Research objectives: to summarize the modern achievements of the science of managing complex social systems, self-organizing.

\section{Material and Methods of the research}

Methods: analysis of literary sources; analysis of documents; system analysis; historicism method; a method of analogy of observed patterns; mathematical modeling method.

\section{Results of the research}

The process of globalization, which takes place all over the world, covers all types of interstate relations, which leads to the creation of all kinds of alliances, blocs, alliances, and legends that are fiercely competitive for a dominant global position on the planet. Such a struggle affects all spheres of their interactions - in economic, cultural, political and scientific, forming a general regulation of relations. The determination of these processes is based on the basic principles of the flow of self-organizing.

Competition in each area of activity of interdependent interstate relations has an independent character, which determines the features of their priority orientation, both of an individual state and at the level of interstate relations. This gives rise to features of the course of competition in each of the spheres of activity both within the state and at the leve of interstate relations. The nature of these relationships may be different. When analyzing the nature of these relations, it is necessary to take into account the levels of their organization, based on the theory of synergetic systems. In the globa system of interstate relations, each of the states acts as a "connected" system (agency) in competitive relations, the formation of a unified international system in which the partia significance that each of them brings into the corresponding sphere of social relations is formed. The results of these areas of activity within each of the states should be considered as those occurring in the "autonomous" system. Moreover external relations are considered as controlling parameters in relation to this domestic sphere of activity. A complete set of the presence of all the marked parameters, taking into account the need to know the different dynamics of their course and achieve synchronization of complex interdependent relationships, can only be represented as the structure of the levels of their mathematical description. A verbal description of this process is practically not possible, especially since it is necessary to take into account the tolerance of the space of its course and the number of sides in the structure [4].

In 1968, L. Bertalanfi put forward the systemic concept of the "general theory of systems", whose task was to develop a mathematical apparatus for describing various types of systems [8; 10; 16]. Almost simultaneously with the "general theory of systems" L. Bertalanfi was developed by the "theory of functional systems" by K. P. Anokhin, which substantiates not only the need for the presence of differentiated structures in the system, but also the consideration of their participation in obtaining the final result depending on the conditions the course of adaptation-compensatory processes of the system in question, aimed at maintaining its equilibrium state with the environment $[1 ; 16]$.

In contrast to the "general theory of systems" L. Bertalanfi, representing the interaction of constant average criteria the "theory of functional systems" by K. P. Anokhin justifies the continuous mobility of partial significance of interdependent systems in the formation of the final equifinal results obtained with minimal cost to achieve it . In fact, the theory of K. P. Anokhin appeared as a necessary complement to the general theory of systems of L. Bertalanfi. It should be noted that in the "general theory of systems" L. Bertalanffy did not answer the question about the mechanism, which gives rise to the emergence of differentiated structures in the process of forming an integrated system, was formulated by the author as a "development paradox". In turn, in the "theory of functional systems" by K. P. Anokhin, in which the necessity of having a mechanism for observing the variability of the medium and satisfying the need to maintain the equilibrium state of the system was revealed, the source's question remains unclear, which gives rise to its functioning $[1 ; 16]$.

At the same time, L. A. Zade's "theory of fuzziness" is a kind of apparatus for the analysis and modeling of "humanistic systems", that is, systems in which "man" is involved. His approach is based on the premise that the elements of thinking are not numbers expressing the final result, but elements of some fuzzy sets for which the transition from "belonging", that is, "yes" to "non-belonging", that is, "no" is not abrupt but continuous. In the future, this theory received the definition of "human-machine systems", and in a more general case - the theory of systems" human-control object - environment" [17].

A little later (1977-1978), the theory of synergetic systems appeared. The main point of synergetics is the consistency of interdependent elements of the system in their relations. This new scientific direction was named on the initiative of G. Hagan - synergetics [14]. As a scientific theory, synergetics was aimed at studying systems consisting of many subsystems of various nature. This allowed us to consider the question of how the interaction of such subsystems leads to the emergence of spatio-temporal structures at macroscopic scales. Of particular interest were those situations where the structure arose as a result of self-organization, which made it possible to elucidate the principles of controlling the process of self-organization regardless of the nature of the subsystems [12]

The development of a generalized concept of the system, including the contribution of all the theoretical provisions of the theories considered, has led to a deeper understanding of the category of "norm". From the general presentation of the norm, Hegel (1977-1980) was sufficiently deeply substantiated. The concepts arose: "population norm", "regional norm" and, finally, "individual norm". The concepts of "state of norm" and "norm of state" began to be considered. The norm passed from the imagination of some frozen criterion of quantitative characteristic into the imagination of the dynamic process, provides the equilibrium state of the organism, and in the general case the equilibrium state of the system with its environment [5; 11].

The dynamics of the continuous course of the adaptation process of the norm of relations of an object with its environment was disclosed in the works of V. M. Samsonkin [13]. Such an approach made it possible to reveal the speed of the process under consideration, the level of possible complexity of its organization, the reasons for the differentiation of the morphogenesis of organs that determine the viability of a holistic structural formation, which in different areas of life can be characterized as an organism, state, humanistic system, or the "human-control object-environment". The emergence of a need entails the need for its satisfaction as a natural act 


\section{СЛОБОЖАНСЬКИЙ НАУКОВО-СПОРТИВНИЙ ВІСНИК}

aimed at maintaining the equilibrium state of the system with the environment. The appearance of this type of differentiated structural and functional areas, such as a response to the action of various environmental factors, give rise to a structure of interdependent relationships that determine the organization of a holistic system. Depending on the degree and plasticity of mutual coordination or synchronization of their interaction, the "norm" of a stable state of integrity of the state of the system is determined. The occurrence of such dynamics of the "norm" of the state requires the presence of a certain tolerance in all structural formations (sectors) to ensure coordinated interaction [11].

So, in each specific time period, we can talk about the "norm of state" and "state of norm." Each differentiated structural and functional component, as well as each of its constituent elements, is a "flow cultivator", which requires the necessary provision for the volume of mass interchange and the speed of their mediation. Maintaining the appropriate state of the system depends on the potential capabilities of such support. Thus, it is necessary to consider the sphere of physical culture as an "open dynamic system". The continuity of the process is necessary, the pleasure of energy exchange and the necessary stream of conversion of brown substances can be realized in special forms of depositing the results of the activities of functional systems to meet emerging needs. This gives rise to the corresponding "triad of relations" between the emerging need, its ability to solve and the degree of satisfaction of existing needs.

The most effective option will be that which is achieved with less energy and mass transfer. The principle of "least action" and the principle of "bottleneck" dichotomous to him are these necessary components of the mechanism for the continuous search for the most economical option for solving the emerging need. An indicator of the success of this process is the degree of satisfaction with the final result. The mechanism of operational adaptation lies in this triad; it proceeds continuously on the basis of the available possibilities of mutual energy-mass transfer, which ensures the possibility of solving the current state. The determining process for the successful course of operational adaptation is the synchronization of the interaction of "connected systems" among themselves in the conditions of changing tolerance of their relations. Adaptation as a whole must be considered as a process and as a phenomenon, as a structure that allows the transformation of environmental conditions into a structure of internal transformations to maintain an equilibrium state [2].

The violation of the synchronization process is based on the nature of the deposit mechanism, which leads to changes in localized needs in interdependent relationships towards a decrease in the differentiated support function and an increase in local tolerance. Establishing an acceptable deposit criterion limits the level of desynchronization of the interaction of system elements. When this process proceeds beyond the limits of noticeable control, the desynchronization that accumulates becomes latent and its change can be described by the method of slowly changing parameter. At the same time, it is necessary to distinguish between two types of deposits: their differentiated result of functional activity as a reserve for unexpected demand in mutual support and the deposit for themselves of products of differentiated activity, security from other interrelated "connected systems". Both forms of deposit are conditions for the regulation of fluctuations in the relationship "request-pleasure" or "need-permission-satisfaction". Each of the forms of escrow requires the expenditure of potential capabilities from its total supply to ensure these types of deposits. In violation of permissible norms, this leads to a decrease in the viability of a holistic system and desynchronization of its components are interdependent life support systems [15].

Depending on the availability of potential security opportunities, their partial use is determined to obtain the final result. The "statistical" principle of the equifinality of its production and the principle of "minimum" determine at each stage of complication of the organization of a holistic system the partial use of those options of a ranked series of structural and functional differentiation of "related education" in which the use of the system's potential capabilities in ensuring the necessary result is achieved with a minimum of costs. The principle of "minimum" allows you to save and deposit the total potential and to redistribute it in mutually dependent relations, to ensure the viability of an integral state, or to form any "industry" that is incomplete as a "connected body". The bottleneck principle signals that there is a weak link in the general organization that requires an active expenditure of potential to strengthen it. The relationship between the principle of "minimum" and the principle of "bottleneck" is described as a "consumer-satisfactory", for which the Volterra-Loka mathematical model of this process is widely used [3].

In the verbal description of the dynamics of the process, significant difficulties arise due to different terminology in each field of knowledge in which this problem is studied. In the theory of synergetic systems, a mathematical apparatus has been developed that allows us to establish a unified nature of the process and to carry out its research using the method of mathematical modeling, which is the only one possible in the analysis of social, environmental and other complex macrosystems, where any experiment is excluded in essence the impossibility of its implementation to establish the truth of the nature of the investigated phenomenon [13].

A significant feature of the use of this method is that it has a great opportunity to solve the tasks that remain unavailable in the classical methods of their consideration. The most important in this regard are the regularities of differences in the levels of systemic organization, and the consequences of assessing the impact of the statistical principle of obtaining the same equifinal result when comparing different levels of its formation. In each case, the imagination of the significance of the contribution of the previous level is based on the average indicator of the "norm", where it acts as a specific number. As you move away from the average statistical level, this value is perceived completely differently in each section of the distance from the zone of plastic construction of interdependent relationships.

This imposes requirements on the need to establish a ranked series of significance of the obtained equifinal result at the previous level of its provision for its distribution according to rank demand of the highest level. The allocated zone of plastic construction of interdependent relationships represents the highest density of all possible variations in the construction of mutually complementary forms of organization of behavior, the dynamics of which are aimed at maintaining the stability of the equilibrium relationship with the environment. Continuous reproduction of these forms of joint mutually reinforcing behavior proceeds according to clearly determined rules for constructing the norms of the process of conditioning the equilibrium state of system integrity. Such coordination of relations is based on declarations and acts of declarative and recommendatory nature $[6 ; 8]$.
Korolova, M. (2019), "Legal bases of sports activity as an object of the theory of system organization", Slobozans 'kij naukovosportivnij visnik, No. 5(73), pp. 35-39, doi:10.15391/snsv.2019 5.005 


\section{SLOBOZANS'KIJ NAUKOVO-SPORTIVNIJ VISNIK}

So, the process of stochastic variation of the environment from which energy consumption is compensated to maintain the stability of a viable system integrity is consistent with the operational adaptation mechanism to ensure the level of energy potential of long-term reliability. This process is carried out as a result of the energy-mass flow entering the whole system from the external environment.

\section{Conclusions / Discussion}

It has been established that at the present stage of development of public sports associations, the international sports movement and international sports federations, successful managerial activity can only be based on the position of its construction based on systems theory. Having arisen in relation to one period of time, but in different countries, each of the theories of system organization has revealed important components of the self-organization process, which, being combined into a generalized theory of systems that allow model construction of the self-organization process. It was revealed that L. Bertalanffy's theory of systems reveals the essence of structural morphogen- esis of the organogenesis of a system, but does not explain the mechanism of how system elements are formed.

The theory of K. P. Anokhin makes a significant contribution to understanding the functioning of structural morphogenesis or generated industries in the overall functional activity. The emergence of the theory of humanistic systems or systems "man - the control object - the environment" pays attention for the first time to the process of self-organization in fuzzy or tolerant spaces, introduces the concept of permissible error, the introduction of man as a natural component of humanistic systems allowed us to establish not only its significance in the structure of these systems, but also drew attention to the fact that a person in humanistic systems is the weakest link and the main cause of critical situations, which in most cases end in disasters. It is established that the process of formation of interdependent relations is based on the general principles of interaction of the object in question and its environment. It is the interaction of the object and the environment as a whole that acts as one of the determining principles of the observed self-organization, the essence of which is the constant preservation of the equilibrium state in this interaction.

Conflict of interests. The author declares that no conflict of interest. Financing sources. This article didn't get the financial support from the state, public or commercial organization.

\section{References}

1. Anokhin, K.P. (1974), "The General Theory of Functional Systems of the Body", Progress v biologicheskoy i meditsinskoy kibernetike, Moscow, pp. 52-110. (in Russ.)

2. Artemeva, G.P., Pugach, Ya.I. \& Druz, V.A. (2014), Problema adaptatsii u strukture nauchnykh issledovaniy sistemy olimpiyskogo obrazovaniya: monografiya [The problem of adaptation in the structure of scientific research of the Olympic education system], Kharkiv. (in Russ.)

3. Volterra, V. (1976), Matematicheskaya teoriya borby za sushchestvovanie [The mathematical theory of the struggle for existence], Moscow. (in Russ.)

4. Voronov, A.A. (1979), Ustoychivost, upravlyaemost, nablyudaemost [Stability, controllability, observability], Moscow. (in Russ.)

5. Gegel, G. (1975), Nauka logiki [Science of Logic], Vol. 1, Moscow, pp. 257-263. (in Russ.)

6. Gorban, A.N. \& Khlebopros, R.G. (1988), Demon Darvina. Ideya optimalnosti i estestvennogo otbora [The Demon of Darwin. The idea of optimality and natural selection], Moscow. (in Russ.)

7. Denisov, A.A. \& Kolesnikov, D.N. (1982), Teoriya bolshikh sistem upravleniya [Theory of large control systems], Leningrad. (in Russ.)

8. Kalman, R., Falb, P. \& Arbir, M. (1971), Ocherki po matematicheskoy teorii system [Essays on the mathematical theory of systems], Moscow. (in Russ.)

9. Ketle, L.A. (1911), Sotsialnaya fizika [Social Physics], Sankt-Peterburg. (in Russ.)

10. Kukhtenko, A.I. (1969), "Overview of the main directions of development of the general theory of systems", Materialy koordinatsionnogo soveshchaniya sektsii tekhnicheskoy kibernetiki Nauchnogo soveta po kibernetike ANUSSR, Kiev. (in Russ.)

11. Plakhov, V.D. (1985), Sotsialnye normy. Filosofskie osnovy obshchey teorii [Social norms. Philosophical foundations of the general theory], Moscow. (in Russ.)

12. Prigozhin, I. (1985), Ot sushchestvuyushchego k vozmozhnomu [From the Existing to the Possible], Moscow. (in Russ.)

13. Samsonkin, V.N., Druz, V.A. \& Fedorovich, Ye.S. (2010), Modelirovanie v samoorganizuyushchikhsya sistemakh [Modeling in selforganizing systems], Donetsk. (in Russ.)

14. Khagan, G. (1985), Sinergetika ierarkhii neustoychivostey u samoorganizuyushchikhsya sistemakh i ustroystvakh [Synergetics of the hierarchy of instabilities in self-organizing systems and devices], Moscow. (in Russ.)

15. Eshbi, U.R. (1966), Printsipy samoorganizatsii, Moscow, S. 314-343. (in Russ.)16. Bertalanffy, L. (1965), General system theory, New York.

17. Zadeh, L.A. (1965), "Fuzzy sets", Information \& Control, No. 12. pp. 94-102.

Received: 05.09.2019

Published: 31.10 .2019

Анотація. Корольова Марина. Правові основи спортивної діяльності як об'єкт теорії системної організації. Сьогодністан розвитку сфери фізичноі культури і спорту характеризується наявністю організаційно-правових проблем на рівні функціонування усіх ї̈ складових (фізичне виховання, професійний чи масовий спорт і т. д.) на шляху вирішення соціально значущих соціальних завдань. Відсутність об'єктивної оцінки поточного стану галузі суспільних відносин, яку охоплює фізична культура і спорт, з огляду на державну політику інтеграції України до міжнародного співтовариства, веде до процесу асиміляції цієї галузі на користь більш сильної сторони у партнерстві, що формується. Мета: проаналізувати діяльність фізкультурно-спортивних організацій з позиції концептуальних положень теорій системної організації. Матеріал і методи: аналіз літературних джерел; аналіз документів; системний аналіз; метод історизму; метод аналогії спостережуваних закономірностей; метод математичного моделювання. Результати: розглянуто проблему управління складними соціальними системами у контексті функціонування галузі спортивного права. Обгрунтовано теоретичні засади самоорганізації колективних взаємообумовлених відносин у сфері фізичної культури з позиції концептуальних положень теорій системної організації. Висновки: з'ясовано, що на сучасному етапі розвитку громадських спортивних об'єднань, міжнародного спортивного руху й міжнародних спортивних федерацій успішна управлінська діяльність може бути заснована тільки за sportivnij visnik, No. 5(73), pp. 35-39, doi:10.15391/snsv.2019 5.005 


\section{СЛОБОЖАНСЬКИЙ НАУКОВО-СПОРТИВНИЙ ВІСНИК}

умови ї̈ побудови на основі теорії систем. Установлено, що процес формування взаємозумовлених відносин заснований на загальних принципах взаємодії розглянутого об'єкта й середовища його існування. Саме взаємодія об'єкта й середовища як єдиного цілого виступає одним з визначальних принципів ефективного управління та запорукою збереження рівноважного стану системи.

Ключові слова: система, спортивне право, сфера фізичної культури і спорту, теорія, середовище, взаємодія.

Аннотация. Марина Королева. Правовые основы спортивной деятельности как объект теории системной организации. Сегодня состояние развития сферы физической культуры и спорта характеризуется наличием организационноправовых проблем на уровне функционирования всех ее составляющих (физическое воспитание, профессиональный или массовый спорт и т. д.) на пути решения социально значимых социальных задач. Отсутствие объективной оценки текущего состояния отрасли общественных отношений, которую охватывает физическая культура и спорт, учитывая государственную политику интеграции Украины в международное сообщество, ведет к процессу ассимиляции этой отрасли в пользу более сильной стороны в партнерстве, которая формируется. Цель: проанализировать деятельность физкультурно-спортивных организаций с позиции концептуальных положений теории системной организации. Материал и методы: анализ литературных источников; анализ документов; системный анализ; метод историзма; метод аналогии наблюдаемых закономерностей; метод математического моделирования. Результаты: рассмотрена проблема управления сложными социальными системами в контексте функционирования отрасли спортивного права. Обоснованы теоретические основы самоорганизации коллективных взаимообусловленных отношений в сфере физической культуры с позиции концептуальных положений теории системной организации. Выводы: установлено, что на современном этапе развития общественных спортивных объединений, международного спортивного движения и международных спортивных федераций успешная управленческая деятельность может быть основана только при условии ее построения на основе теории систем. Установлено, что процесс формирования взаимообусловленых отношений основан на общих принципах взаимодействия рассматриваемого объекта и среды его существования. Именно взаимодействие объекта и среды как единого целого выступает одним из определяющих принципов эффективного управления и залогом сохранения равновесного состояния системы.

Ключевые слова: система, спортивное право, сфера физической культуры и спорта, теория, среда, взаимодействие.

\section{Відомості про авторів / Information about the Authors}

Корольова Марина Вікторівна: кандидат юридичних наук, Харківська державна академія фізичної культури: вул. Клочківська 99, м. Харків, 61058, Україна.

Королёва Марина Викторовна: кандидат юридических наук, Харьковская государственная академия физической культуры: ул. Клочковская 99, г. Харьков, 61058, Украина.

Maryna Korolova: PhD(Juridical Sciences), Kharkiv State Academy of Physical Culture: 99 Klochkivska Str., Kharkiv, 61058, Ukraine.

ORCID.ORG/0000-0003-2931-2190

E-mail: svetlanastadnik87@gmail.com 